Forthcoming in The Canadian Review of Sociology

\title{
Is a "Christian America" a More Patriarchal America? Religion, Politics, and Traditionalist Gender Ideology
}

\author{
Andrew L. Whitehead \\ Clemson University \\ Samuel L. Perry \\ University of Oklahoma
}

\begin{abstract}
Recent research shows that Americans who adhere to Christian nationalism-an ideology that idealizes and advocates a fusion of Christianity and American civic life-tend to hold authoritarian and exclusionary attitudes, particularly regarding ethno-racial minorities and nontraditional family forms. Such findings suggest a fundamental connection between Christian nationalism and rigid symbolic boundaries, which would likely extend to Americans' understanding of gender roles. Drawing on notions connecting religious nationalism with defenses of patriarchal norms and utilizing a recent national, random sample of American adults, the current study examines the link between contemporary Christian nationalism and traditionalist gender ideologies. Our analyses reveal that Christian nationalism is the strongest predictor of holding a more traditionalist gender ideology, even after taking into account a host of political and religious characteristics. Moreover, the relationship between Christian nationalism and gender traditionalism holds across religious traditions, including more genderegalitarian groups like Mainline Protestants and even the unaffiliated. We conclude by highlighting the implications of these findings for understanding contemporary populist support for Donald Trump, which previous studies have shown is undergirded by both Christian nationalism and sexism.
\end{abstract}

Keywords: Religion, Populism, Gender, Sexism, United States, Christian nationalism 
A persistent and prominent narrative deployed by Donald Trump, both as a populist candidate and as a president, is that America must return to her Christian roots (Gorski 2017a; Jenkins 2017). This appeal has resonated with a large portion of the American population, particularly older, white, working-class Christians, so much so in fact, that holding such a belief-what may be termed "Christian nationalism"-was among the strongest predictors of voting for Trump in 2016 (Stewart 2018; Whitehead, Perry, and Baker 2018). Importantly, Christian nationalism bolsters Trump's populist appeal not merely as a direct response to Trump's self-advertisements as a defender of religious freedom, but also indirectly through its connection to other predictors of Trump support, such as racism, Islamophobia, gun rights, xenophobia, homophobia, authoritarianism, and traditional views of the family (Brubaker 2018; Davis 2018a; McDaniel, Nooruddin, and Shortle 2011; Merino 2010; Perry and Whitehead 2015a, 2015b; Straughn and Feld 2010; Whitehead and Perry 2015; Whitehead, Schnabel, and Perry 2018). What has yet to be explored, however, is the extent to which contemporary Christian nationalism-specifically, an ideology that idealizes and advocates a fusion of Christianity and American civic life-may be closely linked with another ideology associated with Trump's brand of "MAGA" populism, namely, traditionalist views of gender roles and norms (Bock, Byrd-Craven, and Burkley 2017; Frasure-Yokley 2018; Brubaker 2017; Rothwell, Hodson, and Prusaczyk 2019).

There are several reasons why this connection would be expected. The whole of research on Christian nationalism and Americans' political and social views suggests that a core concern for Christian nationalists is the protection of symbolic boundaries, including which religious or ethnic groups should be considered "American" (Edgell and Tranby 2010; McDaniel et al. 2011; Merino 2010; Shortle and Gaddie 2015; Stewart, Edgell, and Delehanty 2018; Straughn and Feld 2010), which families count as legitimate (Perry and Whitehead 2015a, 2015b; Whitehead and 
Perry 2015), and the extent to which Americans feel justified in defending sacred individual rights or national interests (Froese and Mencken 2009; Whitehead et al. 2018). Given this concern with symbolic boundaries, it would be reasonable to expect that adherents to Christian nationalism would prefer unambiguous, traditional roles and expectations for men and women. Along with this, recent research (Davis 2018a) suggests that Christian nationalist ideology is a strong predictor of authoritarian views on social control, and thus, Americans who adhere to Christian nationalism would likely advocate for hierarchical gender relationships, a cultural artifact resulting from a particular, traditional interpretation of authority. Last, at a broader cultural level, Riesebrodt (1993) theorized that the primary critique of populist movements advocating a more prominent role for religion in civic life was the undermining of the patriarchal family structure. Such groups contend that the decline of patriarchy undermines the family and subsequently all society, and thus, must be bolstered by reinvigorating civic life with "fundamental" religious values.

While previous research has identified religion and politics as important correlates of gender ideology (see Carlson and Lynch [2013] and Davis and Greenstein [2009] for reviews), such studies tend to neglect the significant overlap of religion and politics in the minds of Americans and in the social context at large (but see also Brubaker 2017; Davis and Robinson 1996). Identifying the degree to which Americans are comfortable with, or even actively desire, a close relationship between Christianity and American political institutions allows us to account for this overlap.

Analyzing data from a recent, national random sample of American adults, our study makes three important contributions. First, it demonstrates that embracing Christian nationalism is the strongest predictor of espousing a more traditionalist gender ideology for Americans, net 
of their religious and political characteristics. Second, it establishes that this relationship holds within certain religious and even non-religious groups usually identified as both opposed to Christian nationalism and generally more egalitarian. This finding highlights the usefulness of Christian nationalism as a measure of public expressions of religion which are not merely proxies for private religiosity (Braunstein and Taylor 2017; Stewart et al. 2018; Delehanty, Edgell and Stewart 2018). It also highlights the importance of cultural factors in predicting social attitudes above and beyond denominational affiliation. Third, while we cannot definitively establish causal direction, our findings indicate that, due to their strong association, increases in one ideology—either Christian nationalism or gender traditionalism—will be mirrored by increases in support for the other. In our conclusion we will highlight the implications of these findings for better understanding Donald Trump's populist appeal.

\section{Christian Nationalism in the United States}

We follow Gorski (2017b; see also Bellah 1967) in distinguishing America's “civil religion" tradition, which historically served as an inclusive and justice-oriented ideal that united Americans, from Christian nationalism, which in some forms is exclusivist, hawkish, and fundamentally concerned with symbolic and social boundaries around a distinct group identity, which we explore in more detail below. While American civil religion also drew on parallels between the Old Testament people of Israel and the United States, particularly concerning America's covenant responsibility to uphold justice and righteousness, Christian nationalists identify with Israel more literally, especially with regard to Israel's military conquests, required separatism and blood purity, and God's threatened curses for moral decadence (see Falwell 1980:24). Americans who embrace Christian nationalism believe that the United States should be distinctively Christian in its national identity, sacred symbols, and public policies. Christian 
nationalism, therefore, is a cultural framework - a collection of myths, traditions, symbols, narratives, and value systems that are pervasive throughout a society - that creates strong symbolic and social boundaries around a particular national identity that is used to defend claims to power, especially by dominant groups.

Studies exploring Christian nationalism's influence on social attitudes find that adherents to Christian nationalism seem to sacralize social boundaries and thus strongly defend such boundaries. Empirically, this often manifests itself in ethno-religious prejudice and xenophobia. For example, numerous studies have shown that Americans who draw a stronger connection between Christianity and American civic life hold antipathy toward immigrants (McDaniel et al. 2011; Sherkat and Lehman 2018) and are more interested in restricting immigration to the United States (Davis 2018b; Straughn and Feld 2010); they tend to hold prejudicial attitudes toward Muslims (Merino 2010; Sherkat and Lehman 2018; Shortle and Gaddie 2015); and they also tend be prejudiced against black Americans (Perry, Whitehead, and Davis 2018). Christian nationalists also seem to defend symbolic boundaries when it comes to ideal family forms. Perry and Whitehead (2015a, 2015b) find that Christian nationalism is a powerful predictor that white Americans will oppose interracial marriage or transracial adoption (see also Edgell and Tranby 2010). And Whitehead and Perry (2015) show that Christian nationalism also predicts opposition to same-sex marriage or civil unions. Brubaker (2017) argues that American populist movements, like Trumpism, tend to join "identitarian Christianism" with conservative rhetoric around various cultural debates including those about gender.

Another way Christian nationalism seems to bolster symbolic boundaries is at the level of sacralizing conceptions of national interests and individual rights. For example, Froese and Mencken (2009) demonstrate that Christian nationalism (what they called "sacralization 
ideology") strongly predicts support for American military interventions. Similarly, Christian nationalists tend to sacralize the individual freedoms guaranteed in America's founding documents, rendering them beyond revision or reinterpretation. Accordingly, Whitehead, Schnabel, and Perry (2018) show that Christian nationalism is among the strongest predictors of opposition to gun control laws. In both of these instances, Christian nationalism seems to strengthen boundaries around sacred rights, both national and individual. Moreover, these last two studies also contribute to our understanding of Christian nationalism as inherently authoritarian. Recent research confirms this more directly. Davis (2018a) shows that adherence to Christian nationalism powerfully predicts Americans' support for more coercive forms of social control, and Stewart et al. (2018) find that Americans who advocate for a stronger role for religion in civic life tend to be more politically intolerant of religious outsiders.

\section{Theorizing the Link Between Christian Nationalism and Traditionalist Gender Ideology}

We theorize three potential mechanisms connecting Christian nationalism and traditionalist gender ideologies in the United States: overlapping symbolic boundaries, mutually reinforcing social institutions, and gendered narratives of American civic participation.

Both Christian nationalist thought and patriarchal cultural ideologies, though conceptually distinct from one another, share commitments to a cultural vision idealizing "traditional" and authoritarian social arrangements. They also share perceptions that such arrangements are under attack. Consequently, the two ideologies advocate complementary and overlapping symbolic boundaries demarcating what they perceive to be ideal social and familial situations. Pining for a return to a mythical era in which "Christian values" and "Christian identity" were givens, Christian nationalists tend to draw boundaries around patriarchal conceptions of "the family" (Perry and Whitehead 2015a, 2015b; Whitehead and Perry 2015). 
This is consistent with Riesebrodt's (1993:70) theory that the "traditional patriarchal nuclear family" is a key area of focus for those advocating various forms of religious nationalism. Such groups consistently define "strong families" as the fundamental building block of society, and of America in particular. "Strong families" in this view, however, are only those they define as "biblical" or "traditional," namely, between heterosexual men and women, with a clear division of labor-where men are leaders, protectors, and breadwinners and women take on homemaking and childrearing roles (Riesebrodt 1993:34-46). In the American context, Christian nationalist thought-leaders often argue that America's future success depends on its citizens recognizing the importance of God's design for men and women. For instance, Rafael Cruz (father of Texas senator Ted Cruz) warns against disregard for gender as one of the key threats facing America, "The gender lines could become blurred, and the family fundamentally redefined... When the ship of righteousness departs from the proven route established by Scripture, a crash will occur" (Cruz 2016:165, 167). Others, reflecting this mindset, locate America's existing social problems with men abdicating their divinely-ordained authoritative roles: "American men walked out on their God-given responsibility for moral and spiritual leadership in the homes, schools, and Sunday schools of the nation" (Hardenbrook 2006:379; see also Smith 2000).

Both Christian nationalism and gender traditionalism are also mutually constituted by shared social institutions found in conservative Christianity. Certainly, Americans within conservative Christian communities may be directly influenced to subscribe to both Christian nationalist ideals and traditionalist gender ideologies through the writings of popular Christian

\footnotetext{
${ }^{1}$ A number of groups committed to changing public policy to more closely align with their Christian worldview include "family" in their name and identify it as central to their mission. The Family Research Council, Focus on the Family, and the American Family Association are some examples. Those interested can find the mission and/or philosophical statements highlighting the central place of "the family" for each group on their websites: American Family Association: http://www.afa.net/who-is-afa/our-mission/. Family Research Council: http://www.frc.org/mission-statement.

Focus on the Family: http://www.focusonthefamily.com/about_us.aspx.
} 
leaders (e.g. Köstenberger and Jones 2010) or through the activism of groups committed to creating a more "Christian" United States such as the Family Research Council, Focus on the Family, or the American Family Association. But this internalization of both ideologies may be imparted in more mundane, indirect ways as well. In her ethnographic account of evangelical congregations in the United States and Canada, Bean (2014) describes how both Christian nationalist ideals and symbolic reinforcements of traditional gender norms were reinforced through everyday interactions and ostensibly "non-political" religious rituals.

Lastly, another mechanism through which Christian nationalism may be linked to traditionalist understandings of gender is through dominant male-centric narratives of American civic participation. For instance, conservative Christian communities often teach a "creation" narrative of the U.S., which tends to sacralize the role of the "founding fathers" (e.g., Huckabee 2015). Additionally, because Christian nationalism often valorizes militarism and conquest (Froese and Mencken 2009; Gorski 2017b), things often thought as inherently masculine, its intrinsic narrative lends itself to traditional, patriarchal conceptions of gender roles.

Importantly, while we obviously recognize vital connections between religious and political conservatism and Christian nationalism, we argue that Christian nationalism is not merely a proxy for religious or political conservatism alone, but one that operationalizes the significant overlap of the social institutions of religion and politics (Whitehead and Perry 2015). Religion and politics are closely linked in the American social context and especially in many Americans' understanding of the nation's founding, its relationship with the Christian God, and its destiny (Gorski 2017b; Riesebrodt 1993). While prior work demonstrates that both religion and politics influence Americans' gender ideologies (Ammons and Edgell 2007; Bolzendahl and Myers 2004; Davis and Greenstein 2009; Denton 2004; Whitehead 2012), the current study 
examines how a particular cultural framework - Christian nationalism — is associated with traditionalist gender ideologies in a way that is distinct from the usual religion and politics measures. In view of prior research on Christian nationalism and gender traditionalism, our first hypothesis states:

H1: Net of all other effects, Christian nationalism will be positively associated with gender traditionalism.

Prior research highlights that people's gender ideologies vary across different religious traditions (Bartkowski 2001; Gallagher 2003; Gay et al. 1996; Whitehead 2012). Evangelical Protestants are most likely to be comfortable with a Christian nationalist ideology. ${ }^{2}$ Thus, it may be that there is little variation among them regarding our measure of Christian nationalism, thereby rendering the measure superfluous to understanding their views toward gender traditionalism. Because recent research suggests that the "Christian nation" narrative is held by non-evangelical Americans as well (Braunstein and Taylor 2017; Delehanty et al. 2018), it is important to discover if variation in Christian nationalist ideology is predictive for individuals in other religious traditions who also traditionally hold patriarchal views of family and gender (e.g., Catholics) as well as those who are more egalitarian (e.g., Mainline Protestants and the unaffiliated). Based on our arguments about how Christian nationalism may be meaningfully related to Americans' gender ideology, we anticipate that the association between the two will transcend religious tradition. Stated more formally, we expect:

H2: Net of all other effects, Christian nationalism will be positively associated with gender traditionalism for Evangelical Protestants, Mainline Protestants, Catholics, and the unaffiliated.

\footnotetext{
${ }^{2}$ Ancillary analyses of the 2017 Baylor Religion Survey (available upon request) demonstrate that Evangelical Protestants have the highest mean score on the Christian nationalism scale (15.18) compared to Mainline Protestants (11.16), Catholics (12.18), or the Unaffiliated (5.21). However, as Smith (2000) conclusively demonstrates, "ordinary" rank-and-file Evangelical Protestants espouse many contradictory and diverse beliefs concerning a "Christian America." Not all Evangelicals are comfortable with Christian nationalist ideology and some oppose it.
} 


\section{Methods}

\section{Data}

We use data from the fifth wave of the Values and Beliefs of the American Public Survey, also known as the 2017 Baylor Religion Survey (BRS). The 2017 BRS was administered by the Gallup organization and is a national, random sample of 1,501 American adults. The 2017 BRS was a self-administered pen and paper survey with a mail-based collection. The sample was selected using address-based sample methodology on the basis of a simple stratified sample design. This method helps to manage the coverage problems of telephone-based samples and ensures coverage for various subpopulations (younger, African American, Hispanic). The following analyses use sampling weights constructed to match the known demographic characteristics of the U.S. adult population. A total of 1,501 completed surveys returned from an original sampling frame of 11,000 results in a 13.6 percent response rate. ${ }^{3}$ The 2017 BRS is ideal for this research question because it is the most recent national, random survey of American adults that includes both measures of Christian nationalism and gender traditionalism.

\section{Measures}

Gender traditionalism. The dependent variable in this analysis is a gender traditionalism index consisting of four questions. The 2017 BRS asks for respondents' level of agreement (Strongly disagree to Strongly agree) with the following statements: (1) "Men are better suited emotionally for politics than women," (2) "It is God's will that women care for children," (3) "A preschool child will suffer if his or her mother works," and (4) "A husband should earn a larger

\footnotetext{
${ }^{3}$ While lower than desirable, this response rate exceeds the average response rate for many public opinion polls (Pew Research Center 2012), and recent scholarship shows that the accuracy of parameter estimates are minimally related to response rates (Singer 2006). Furthermore, a recent analysis demonstrates that surveys weighted to match population demographics provide accurate data on most political, economic, and social measures (Pew Research Center 2012). Please see Whitehead, Perry, and Baker (2018) and Perry, Whitehead, and Davis (2018) for supplementary comparison tables of the 2017 BRS and the 2016 General Social Surveys.
} 
salary than his wife." Factor analysis demonstrates that these four questions all load onto one factor with values above .71. The alpha reliability coefficient for this index is .77. These four items are quite similar to those consistently utilized in gender ideology indexes (Davis and Greenstein 2009). This particular scale ranges from zero to 12 with a mean of 3.44 (see Table 1).

Christian nationalism. The independent variable of interest for this analysis is a Christian nationalism index frequently used in studies on this topic (e.g., Davis 2018a, 2018b; Perry et al. 2018; Whitehead et al. 2018). The index is constructed using six statements where respondents were asked to offer their level of agreement (Strongly disagree to Strongly agree): (1) “The federal government should advocate Christian values," (2) “The success of the United States is part of God's plan," (3) "The federal government should allow the display of religious symbols in public places," (4) "The federal government should enforce a strict separation of church and state" (reverse-coded), (5) "The federal government should declare the United States a Christian nation," (6) "The federal government should allow prayer in public schools." The alpha reliability coefficient for this index is 0.86 . The mean score for the index is 11.51 ranging from zero to 24 (see Table 1).

Control variables. Building off of prior literature on gender traditionalism, the following analysis includes a host of control variables. Of particular concern was ensuring that our Christian nationalism measure is not simply a proxy for political or religious conservatism. Thus we include key political and religious characteristics. Respondents were asked to report their political ideology ranging from Extremely Conservative to Extremely Liberal. From this we created three groups: political conservatives, political moderates (contrast category), and political liberals. To account for respondents' traditional religious beliefs we include a measure of Bible views. Respondents could identify their views of the Bible as it should be interpreted literally 
(biblical literalist), that it is perfectly true but must be interpreted (Bible inspired), that the Bible contains some human error (Bible contains errors), that the Bible is an ancient book of history and legends (Bible book of legends), and don't know (Bible don't know). To account for religious practice a standardized and summed scale consisting of frequency of religious service attendance, frequency of prayer, and frequency of reading sacred scriptures is included. Each measure loads onto the same factor with scores above .86 . The alpha coefficient for the scale is .85. This measure of religious practice is an improvement over using only religious service attendance in that it captures religious practice across a variety of traditions and includes private religious activities. Finally, the analyses account for religious affiliation which includes the following religious traditions: Evangelical Protestant, Mainline Protestant, Black Protestant, Catholic, Jewish, “other” religions, and no religious affiliation. Evangelical Protestants serve as the contrast category.

Socio-demographic control variables shown to influence gender ideology in prior research are also included in the multivariate models. These include: age (in years), gender ${ }^{4}$ $($ female $=1)$, marital status $($ married $=1)$, race $($ white $=1)$, region $($ south $=1)$, size of place (rural $=1$ ), education level (less than high school, high school graduate, some college, college graduate

\footnotetext{
${ }^{4}$ In their study of gender traditionalism among conservative Protestants, Bartkowski and Hempel (2009) examine the influence of strength of affiliation, religious attendance, and theological conservatism for men and women separately and discover significant differences between sexes. We performed difference of means tests for the Christian nation scale among women and men. We find that the mean for Christian nationalism is significantly higher $(\mathrm{p}<0.001)$ for women than for men. Because of this difference we examined the association between Christian nationalism and gender traditionalism among men and women separately in ancillary analyses. The results for men and women are identical and follow those in the full model presented below. We also created an interaction effect between Christian nationalism and gender in the full model. The interaction was non-significant. Taken together, these additional analyses (available upon request) suggest that while there is a significant difference for the mean scores between women and men on the Christian nationalism scale, the variation of women and men along the scale and around those means is similar enough that the effect of Christian nationalism on gender traditionalist attitudes is identical for both genders.
} 
[contrast category], post-graduate), and income ( $\$ 20,000$ or less, $\$ 20,001-35,000, \$ 35,000$ -

$50,000, \$ 50,001-100,000$, and $\$ 100,000$ or more [contrast category]).

\section{Methods}

The analysis proceeds in a number of steps. First, the descriptive statistics of the sample and bivariate associations of all the covariates are presented in Table 1 and Figure 1. Table 2 presents the results of the ordinary least squares (OLS) regression analysis for the entire sample. Figure 1 also displays the predicted values on the gender traditionalism scale for the full model in Table 2. Due to the distribution of the gender traditionalism index, OLS regression is the appropriate multivariate technique. Table 3 includes the results of the full model for Evangelical Protestants, Mainline Protestants, Catholics, and the Unaffiliated, respectively. To correct for missing data, multiple imputation (MI) techniques are employed in order to avoid potential bias in test statistics and standard errors when using listwise deletion and to also take advantage of available data (Allison 2002). All subsequent results use the MI dataset. In order to assess substantive significance alongside statistical significance, Tables 2 and 3 display standardized regression coefficients. Finally, figure 2 graphs the predicted scores on the gender traditionalism scale at each point of the Christian nationalism scale for all models found in Table 3. All significant correlates other than the Christian nationalism measure are held at their means or measure of central tendency. Prediction lines for Evangelical Protestants, Mainline Protestants, Catholics, and the Unaffiliated are included. ${ }^{5}$

\section{Results}

\footnotetext{
${ }^{5}$ Please note that the unaffiliated and Mainline Protestant prediction lines end at 21 because no respondents in these groups scored a 22 on the Christian nationalism scale, with just five Mainline Protestants scoring a 23 and none scoring a 24, and just three unaffiliated respondents scoring a 24 with none scoring a 23.
} 
Table 1 and Figure 1 clearly demonstrate a strong bivariate association between Christian nationalism and gender traditionalism. These two measures are strongly correlated $(r=.49$; $\mathrm{p}<.001)$. At the lowest score on the Christian nationalism scale, the corresponding mean gender traditionalism score is 1.22 increasing to 3.07 at the middle value on the Christian nationalism scale which is slightly lower than the mean for the gender traditionalism scale in the overall sample (3.44) (see Figure 1 and Table 1). At the highest point on the Christian nationalism scale, the mean gender traditionalism score is 5.07, just under one standard deviation higher than the sample mean.

Model 1 in Table 2 includes the socio-demographic measures with gender, income, region of the country, and education maintaining the strongest association with gender ideology, among other significant covariates. Model 2 includes the religion controls and doubles the proportion of variance explained. In order of strength of association, religious practice, gender, Bible views, education, and region of the country are all significantly associated with gender ideology. Model 3 includes the political conservatism measures. Respondents who are politically conservative $(\beta=.14)$ or politically liberal $(\beta=-.15)$ are each significantly different than political moderates concerning gender traditionalism. Frequent religious practice and Bible views are each significantly associated with gender traditionalism. Women still score lower on the gender traditionalism scale compared to men. Differences between college graduates and those with lower levels of education and region of the country all maintain significant associations.

Model 4 in Table 2 represents the full model and includes the Christian nationalism measure. Christian nationalism, net of all other effects, is strongly and positively associated with gender traditionalism $(\beta=.33)$ providing clear support for hypothesis 1 . It is by far the strongest 
measure in the model, with a standardized coefficient almost twice the size of the next strongest predictor, gender $(\beta=-.17)$. Accounting for Christian nationalism also increases the proportion of variance explained compared to model 3. The differences between political conservatives and liberals compared to moderates maintain their significant association with gender traditionalism, as does religious practice and the difference between biblical literalist and those who believe the Bible contains errors. Gender, region of the country, and the differences between college graduates and those with lower levels of education all maintain significant associations. Including Christian nationalism accounts for the significant differences between biblical literalists and 1) those who believe the Bible is inspired as well as 2) those who think it is a book of legends. Each was significantly different from biblical literalism in Model 3.

Figure 1 displays the predicted scores on the gender traditionalism scale at each value of the Christian nationalism index using the coefficients from the full model. All of the significant effects are held to their means or measure of central tendency. It is clear that as Americans embrace Christian nationalism the corresponding score on the gender traditionalism scale increases, as well.

Table 3 displays the results of the association between Christian nationalism and gender traditionalism for the Evangelical Protestant, Mainline Protestant, and Catholic religious traditions as well as the unaffiliated. ${ }^{6}$ Across each religious tradition Christian nationalism maintains a significant and positive association with gender traditionalism, providing support for hypothesis 2. For each group_Evangelicals, Mainline Protestants, Catholics, and the unaffiliated - it is the strongest predictor in the model.

\footnotetext{
${ }^{6}$ There were too few Jewish and Black Protestant respondents in the survey to perform multiple regression analyses. The "Other" category is a conceptual catch-all category and so any interpretation of results would be ill-advised.
} 
Figure 2 graphs the predicted scores on the gender traditionalism scale at each value of the Christian nationalism scale for each religious tradition. It is clear that in each religious group, as in the full sample, variation along the Christian nationalism scale is strongly and positively associated with gender traditionalism, net of all other effects. The figure also suggests that the strength of association for the Christian nationalism measure may differ across religious traditions. The slope of the line for Mainline Protestants, for example, is much steeper than that for Evangelical Protestants or the unaffiliated. Traversing from the lowest levels of Christian nationalism to the highest results in a four point increase on the gender traditionalism scale for Mainline Protestants. For Evangelicals, this results in close to a three point increase. We caution against making this interpretation. Interaction terms for Christian nationalism and religious tradition were non-significant meaning the strength of association between Christian nationalism and gender traditionalism is similar for each religious tradition. The key story, rather, is that Americans across each of these groups are more likely to be gender traditionalists the more they embrace Christian nationalism.

\section{Discussion}

Our results demonstrate that Christian nationalism is strongly associated with gender traditionalism, both for the full sample and across religious traditions. Indeed, despite controls for religious and political characteristics, Christian nationalism is the strongest predictor of gender traditionalism in every model. Put simply, identifying the degree to which Americans embrace Christian nationalism reveals more about their views of men's and women's roles in society than knowing their political views, religious beliefs, behaviors, and affiliation, or even their gender. These findings suggest that when Christian nationalism encourages 
"reconstructing" America according to traditional religious ideals, this entails a cultural shift toward a more traditionalist, patriarchal gender ideology (Riesebrodt 1993:95).

What are the specific mechanisms connecting Christian nationalism with traditionalist gender views? As stated previously, overlapping symbolic boundaries, mutually reinforcing social institutions, and gendered narratives of American civic participation may each play a role. Both Christian nationalism and gender traditionalism draw upon a cultural vision that emphasizes "traditional" and authoritarian social arrangements. Americans who embrace Christian nationalism long for a time when patriarchal family arrangements were the norm. As the social institution of the family continues to diversify in modern American life, Christian nationalists will continue to call for returns to what they see as God's design for families. Second, Christian nationalism and gender traditionalism are both reinforced within conservative Christianity by the writings of popular leaders, through organizations committed to advocating for "traditional" family arrangements and a more Christian culture, and within the thousands of congregations spread across the United States. The institutional supports of Christian nationalism, in other words, would also be those that buttress traditionalist gender ideology. Finally, the Christian nation narrative typically emphasizes the role of men and the founding fathers and their relation to the male Christian God. It also accentuates traits like conquest and militarism which are commonly assumed to be more masculine. Christian nationalist conceptions of America's founding advocate that a return to "biblical foundations" (i.e., social relationships based on conservative Christian interpretations of the Bible) are the only hope for America's restoration. In order to truly fulfill its covenant as a Christian nation, Americans must "return" to the traditional patriarchal order and family structure. Doing so will benefit not only individual families, but also the entire country (Riesebrodt 1993). 
Due to the cross-sectional nature of the sample, this analysis also suggests that increases in support for gender traditionalism may very well be mirrored by increases in support for Christian nationalism. It could be that some Americans perceive changes or decline in the family and surmise that a nationwide return to traditional gender roles is necessary. This desire to return the United States and family life to the way it "ought" to be may lead to tighter links between religion and nation. Aggregate levels of Christian nationalism across American society do respond to period effects and cultural events (Whitehead and Scheitle 2018). The ongoing diversification of American family life may continue to activate certain sectors of the population to draw upon particular cultural frameworks, like Christian nationalism. Either way, the strong link between gender traditionalism and Christian nationalism may underscore a shared underlying commitment to moral traditionalism. Religious and cultural conservatives draw on shared moral foundations like in-group loyalty and respect for authority (Haidt 2012). Because both gender traditionalism and Christian nationalism share elements of these moral foundations, it could be that they are linked in the minds of Americans.

This analysis also demonstrates that accounting for Americans' views of Christian nationalism is useful across various religious traditions, and even the unaffiliated. Variation within these groups concerning the public expression of Christianity in civil society matters when predicting gender ideology. This is further evidence of the diffusion of Christian nationalist discourse across American culture (Braunstein and Taylor 2017; Delehanty et al. 2018). While the unaffiliated generally score much lower on the Christian nationalism scale, ${ }^{7}$ those

\footnotetext{
${ }^{7}$ Twenty-four percent of the unaffiliated score at the absolute lowest level of the Christian nationalism scale, a zero. However, almost thirteen percent of the unaffiliated score at or above the mid-point of the Christian nationalism scale (for more on the diversity within the unaffiliated, see Baker and Smith 2009). No unaffiliated respondents scored a 22 or 23 on the Christian nationalism scale, with less than five scoring a 24 . The distributions on the Christian nationalism scale for Evangelical Protestants, Mainline Protestants, and Catholics are much more consistent with a normal distribution (results available upon request).
} 
unaffiliated Americans who score near or even slightly above the mid-point of the scale—suggesting perhaps an ambivalence toward Christian nationalism rather than outright disapproval一still espouse a more traditional gender ideology. This same pattern holds true for Evangelical Protestants, Mainline Protestants, and Catholics: a greater desire for Christianity to be privileged in the public sphere is associated with gender traditionalism. This suggests that Americans who simultaneously support a more Christian and gender traditionalist America can be found across the denominational spectrum. Furthermore, Americans in a religious tradition that is generally much more egalitarian, like Mainline Protestantism, may actually be more traditional in their views toward gender than someone in a religious tradition known for being less egalitarian, like Evangelical Protestantism, due to their different levels of acceptance of Christian nationalist ideology. This finding underscores the importance of accounting for cultural factors, above and beyond denominational affiliation, when examining social attitudes. As Wuthnow (1988) argued decades ago, the restructuring of American religion with widespread denominational change and internal secularization opens the door for particular cultural frameworks — like Christian nationalism—-to play a vital part in framing Americans' responses to shifts in the cultural context surrounding them.

The strong association between gender traditionalism and Christian nationalism demonstrated here despite controlling for the influence of private religiosity provides further support for the importance of measuring Americans' views toward the public expression of religion (Delehanty et al. 2018; Stewart et al. 2018). While Americans who are more religiously active are more gender traditionalist, just like Americans who embrace Christian nationalism, their large and independent effects suggest that they are measuring two different aspects of religion. Researchers interested in the influence of religion on Americans' beliefs and behaviors 
should no longer neglect the importance of public expressions of religion, like Christian nationalism, by only accounting for private measures of religion like affiliation, beliefs, or behaviors.

A few limitations of this analysis also deserve mention. First, the data used to examine the association between Christian nationalism and gender traditionalism are cross-sectional. This precludes making any sort of causal argument. However, in this particular instance it matters little which ideology "comes first;" the analysis aims to demonstrate that the two ideologies in view, Christian nationalism and gender traditionalism, are intimately related. Further, the logic used to explain the connection between Christian nationalism and gender traditionalism follows similar arguments made in the literature concerning the relationship between gender traditionalism and other ideologies. There is no way to examine how gender ideologies are understood and negotiated in families that embrace Christian nationalist rhetoric using the 2017 BRS. Future research utilizing qualitative techniques would better be able to capture how Christian nationalists understand gender roles as well as how those beliefs translate into everyday life.

\section{Conclusion}

The finding that both Christian nationalism (e.g., Whitehead et al. 2018) and patriarchal views of gender (Bock et al. 2017; Frasure-Yokley 2018; Rothwell et al. 2019; Schaffner, MacWilliams, and Nteta 2018) contributed to Trump's populist support and ultimate electoral victory in 2016 is not a coincidence. The two factors, as we have shown, are strongly connected in Americans' minds. Specifically, Americans who believe the United States should be declared a Christian nation, who believe the federal government should advocate Christian values, or believe that the success of the United States is part of a divine plan are also much more likely to 
believe that men are better suited for politics than women, that God desires that women care for children, or that a child suffers if her mother works. Returning the United States to a mythical time characterized by traditional gender roles where men dominate the public sphere and women inhabit the private is vitally connected to a desire to return America to its biblical roots believed to be established by the founding fathers. Clearly, when some Americans desire a more Christian nation, they are also longing for a more gender traditionalist America, as well.

This is significant given the increasing prominence of Christian nationalist leaders and rhetoric since Trump's inauguration, which may portend concurrent challenges to women's societal advances despite positive cultural gains (e.g., the \#metoo and \#timesup movements). It is also significant given that "Trumpism" will surely outlast the Trump presidency, as will the close association of Christian nationalism and gender traditionalism. Various social commentators are now declaring the Republican Party the party of Trump pointing out how he has successfully completed the transformation of the party to one that primarily centers on Americans' identity concerns (e.g., Knowles and DiMuccio 2018; Tharoor 2018). It now, and presumably into the future, reflects and will continue to reflect the hallmarks of Trumpism. Our analysis clearly shows that two of these qualities are Christian nationalism and gender traditionalism. Other work highlights various other aspects of Trumpism, like Islamophobia, that have important and independent effects alongside Christian nationalism (Whitehead et al. 2018). Taken together, these findings help us understand the various sources of Trump's populist support. We expect that as long as Trumpism delivers political and policy victories, there is no reason to believe it will fade from the national scene anytime soon. To this end, future research should explore how these two related belief systems-Christian nationalism and traditionalist gender 
ideology — continue to move in tandem and respond to the current administration, Trumpism, and its influence on the broader political context. 


\section{References}

Aho, J. 2013. "Christian Heroism and the Reconstruction of America." Critical Sociology 39:545-60.

Allison, Paul D. 2002. Missing Data. Thousand Oaks, CA: Sage.

Ammons, S. K. and P. Edgell. 2007. "Religious Influences on Work-Family Trade-Offs." Journal of Family Issues 28:794-826.

Baker, J. O. and B. Smith. 2009. "None Too Simple: Examining Issues of Religious Nonbelief and Nonbelonging in the United States." Journal for the Scientific Study of Religion 48(4):719-733.

Bartkowski, J. P. 2001. Remaking the Godly Marriage: Gender Negotiation in Evangelical Families. New Brunswick, NJ: Rutgers University Press.

Bean, L. 2014. The Politics of Evangelical Identity: Local Churches and Partisan Divides in the United States and Canada. Princeton, NJ: Princeton University Press.

Bellah, R. N. 1967. “Civil Religion in America.” Daedalus 96(1):1-21.

Bolzendahl, C. L. and D. J. Myers. 2004. "Feminist Attitudes and Support For Gender Equality: Opinion Change in Women and Men, 1974-1998." Social Forces 83:759-789.

Bock, J., J. Byrd-Craven and M. Burkley. 2017. The Role of Sexism in Voting in the 2016 Presidential Election. Personality and Individual Differences 119(1):189-193.

Braunstein, R. and M. Taylor. 2017. “Is the Tea Party a 'Religious' Movement? Religiosity in the Tea Party Vs. the Religious Right.” Sociology of Religion 78(1):33-59.

Carlson, D. L. and J. L. Lynch. 2013. "Housework: Cause and Consequence of Gender Ideology?” Social Science Research 42:1505-1518.

Davis, J. 2018a. "Enforcing Christian Nationalism: Examining the Link Between Group Identity 
and Punitive Attitudes in the United States." Journal for the Scientific Study of Religion 57(2):300-317.

Davis, J. 2018b. "Funding God's Policies, Defending Whiteness: Christian Nationalism and Whites' Attitudes towards Racially-Coded Government Spending.” Ethnic and Racial Studies. Forthcoming.

Davis, S. N. and T. G. Greenstein. 2009. “Gender Ideology: Components, Predictors, and Consequences." Annual Review of Sociology 35:87-105.

Delehanty, J., P. Edgell and E. Stewart. 2018. "Secularized Evangelical Discourse and the Boundaries of National Belonging." Social Forces. doi: 10.1093/sf/soy080

Denton, M. L. 2004. “Gender and Marital Decision Making: Negotiating Religious Ideology and Practice. Social Forces 82:1151-1180.

Edgell, P. and E. Tranby. 2010. "Shared Visions? Diversity and Cultural Membership in American Life." Social Problems 57(2):175-204.

Falwell, J. 1980. Listen America! Garden City, NY: Doubleday.

Family Research Council. 2015. "Mission of Organization.” Available at: http://www.frc.org/mission-statement.

Fraser-Yokley, L. 2018. "Choosing the Velvet Glove: Women Voters, Ambivalent Sexism, and Vote Choice in 2016." Journal of Race, Ethnicity, and Politics. doi: 10.1017/rep.2017.35

Froese, P. and F. C. Mencken. 2009. "A U.S. Holy War? The Effects of Religion on Iraq War Policy Attitudes." Social Science Quarterly 90(1):103-116.

Gallagher, S. K. 2003. Evangelical Identity and Gendered Family Life. New Brunswick, NJ: Rutgers University Press. 
Gay, D. A., C. G. Ellison and D. A. Powers. 1996. "In Search of Denominational Subcultures: Religious Affiliation and 'Pro-Family’ Issues Revisited.” Review of Religious Research 38:3-17.

Gorski, P. 2017a. "Why Evangelicals Voted for Trump: A Critical Cultural Sociology." American Journal of Cultural Sociology 5(3):338-354.

Gorski, P. 2017b. American Covenant: A History of Civil Religion from the Puritans to the Present. Princeton, NJ: Princeton University Press.

Haidt, J. 2012. The Righteous Mind. New York, NY: Vintage Books.

Hardenbrook, W. 2006. "Where's Dad? A Call for Fathers with the Spirit of Elijah.” In Recovering Biblical Manhood and Womanhood, Piper, John, and Wayne Grudem (eds.), pp. 378-377. Wheaton, Ill: Crossway.

Huckabee, M. 2015. God, Guns, Grits, and Gravy. New York, NY: St. Martin's Press.

Jenkins, J. 2017. Why Christian nationalists love Trump: God and Country. Think Progress. Available at: https://thinkprogress.org/trumps-christian-nationalism-c6fe206e40cc/.

Knowles, Eric and Sarah DiMuccio. 2018. "How Donald Trump Appeals to Men Secretly Insecure about their Manhood." The Washington Post. Available at: https://www.washingtonpost.com/news/monkey-cage/wp/2018/11/29/how-donald-trumpappeals-to-men-secretly-insecure-about-their-manhood/?utm_term=.e3a8b24f8491.

Köstenberger, A. J. and D. W. Jones. 2010. God, Marriage, and Family: Rebuilding the Biblical Foundation ( $2^{\text {nd }}$ edition). Wheaton, Ill: Crossway.

McDaniel, E. L., I. Nooruddin and A. F. Shortle. 2011. "Divine Boundaries: How Religion Shapes Citizens Attitudes toward Immigrants.” American Politics Research 39: 205-233. 
Merino, S. 2010. “Religious Diversity in a 'Christian Nation': The Effects of Theological Exclusivity and Interreligious Contact on the Acceptance of Religious Diversity." Journal for the Scientific Study of Religion 49:231-46.

Perry, S. L. and A. L. Whitehead. 2015a. "Christian Nationalism and White Racial Boundaries: Examining Whites' Opposition to Interracial Marriage.” Ethnic and Racial Studies 38(10):1671-1689.

Perry, S. L. and A. L. Whitehead. 2015b. "Christian Nationalism, Racial Separatism, and Family Formation: Attitudes toward Transracial Adoption as a Test Case.” Race and Social Problems 7(2):123-134.

Perry, S. L. and A. L. Whitehead. 2016. "For Better or For Worse? Gender Ideology, Religious Commitment, and Relationship Quality." Journal for the Scientific Study of Religion 55(4):737-755.

Perry, S. L., A. L. Whitehead and J. T. Davis. 2018. “God's Country in Black and Blue: How Christian Nationalism Shapes Americans' Views about Police (Mis)treatment of Blacks." Sociology of Race and Ethnicity. doi: 10.1177/2332649218790983

Pew Research Center. 2012. "Assessing the Representativeness of Public Opinion Surveys.” Available at: http://www.people-press.org/2012/05/15/assessing-the-representativenessof-public-opinion-surveys/\#. Last accessed May 22, 2017.

Riesebrodt, M. 1993. Pious Passion: The Emergence of Modern Fundamentalism in the United States and Iran. Berkeley, CA: University of California Press.

Rothwell, V., G. Hodson and E. Prusaczyk. 2019. "Why Pillory Hillary? Testing the Endemic Sexism Hypothesis Regarding the 2016 U.S. Election.” Personality and Individual Differences 138(1): 106-108. 
Schaffner, B. F., M. MacWilliams and T. Nteta. 2018. "Understanding White Polarization in the 2016 Vote for President: The Sobering Role of Racism and Sexism.” Political Science Quarterly 133(1):9-34.

Sherkat, D. E. and D. Lehman. "Bad Samaritans: Religion and Anti-Immigrant and Anti-Muslim Sentiment in the United States." Social Science Quarterly 99(5):1791-1804.

Shortle, A. F. and R. K. Gaddie. 2015. "Religious Nationalism and Perceptions of Muslims and Islam." Politics and Religion 8:435-457.

Singer, E. 2006. “Special Issue on Nonresponse Bias in Household Surveys.” Public Opinion Quarterly 70(5):639-810.

Smith, C. 2000. Christian America? What Evangelicals Really Want. Berkeley, CA: University of California Press.

Steensland, B., J. Z. Park, M. D. Regnerus, L. D. Robinson, W. B. Wilcox, and R. D. Woodberry. 2000. The Measure of American Religion: Toward Improving the State of the Art. Social Forces 79(1): 291-318.

Stewart, E. 2018. "Public Religion and the Vote for Donald Trump: Evidence from Panel Data." Paper Presented at the American Sociological Association Annual Conference in Philadelphia, PA.

Stewart, E., P. Edgell and J. Delehanty. 2018. "The Politics of Religious Prejudice and Tolerance for Cultural Others." The Sociological Quarterly 59(1):17-39.

Straughn, J. B. and S. L. Feld. 2010. “America as a 'Christian Nation'? Understanding Religious Boundaries of National Identity in the United States.” Sociology of Religion 71:280-306. 
Tharoor, Ishaan. 2018. “The Party of Trump Goes Fully Far-Right.” The Washington Post. Available at: https://www.washingtonpost.com/world/2018/11/08/party-trump-goesfully-far-right/?utm_term=.a1b9c3b4f1d4. Last accessed on November 20, 2018.

Whitehead, A. L. 2012. "Gender Ideology and Religion: Does a Masculine Image of God Matter? Review of Religious Research 54:139-156.

Whitehead, A. L. 2014. "Male and Female He Created Them: Gender Traditionalism, Masculine Images of God, and Attitudes toward Same-Sex Unions.” Journal for the Scientific Study of Religion 53(3):479-496.

Whitehead, A. L. and S. L. Perry. 2015. "A More Perfect Union? Christian Nationalism and Support for Same-Sex Unions.” Sociological Perspectives 58(3):422-440.

Whitehead, A. L., S. L. Perry and J. O. Baker. 2018. "Make America Christian Again: Christian Nationalism and Voting for Donald Trump in the 2016 Presidential Election." Sociology of Religion 79(2):147-171.

Whitehead, A. L., and C. P. Scheitle. 2018. "We the (Christian) People: Christianity and American Identity from 1996 to 2014.” Social Currents 5(2): 157-172.

Whitehead, A. L., L. Schnabel and S. L. Perry. 2018. "Gun Control in the Crosshairs: Christian Nationalism and Opposition to Stricter Gun Laws." Socius 4:1-13. 
Table 1: Descriptive Statistics and Bivariate Associations (MI Dataset)

\begin{tabular}{|c|c|c|c|c|}
\hline Variable & Description & Mean or $\%$ & SD & $\begin{array}{c}\text { Correlation w/ } \\
\text { Gender } \\
\text { Traditionalism }\end{array}$ \\
\hline $\begin{array}{l}\text { Gender Traditionalism } \\
(\alpha=0.74)\end{array}$ & $\begin{array}{l}\text { Summed index, } 0=\text { Egalitarian to } 12 \\
=\text { Conservative }\end{array}$ & 3.44 & 2.54 & -- \\
\hline $\begin{array}{l}\text { Christian Nationalism } \\
(\alpha=0.87) \\
\text { Politics }\end{array}$ & Summed index, $0=$ Low to $24=$ High & 11.51 & 6.37 & $.49 * * *$ \\
\hline Politically conservative & & 35.6 & & $.33 * * *$ \\
\hline Politically moderate & Contrast category & 37.2 & & .01 \\
\hline \multicolumn{5}{|l|}{ Religion } \\
\hline Evangelical Protestant & Contrast category & 28.8 & & $.24 * * *$ \\
\hline Mainline Protestant & & 12.4 & & $-.05^{*}$ \\
\hline Black Protestant & & 7.1 & & $.06^{*}$ \\
\hline Catholic & & 25.1 & & -.02 \\
\hline Jewish & & 1.2 & & -.03 \\
\hline Other & & 7.2 & & -.01 \\
\hline No Religion & & 18.1 & & $-.23 * * *$ \\
\hline Biblical literalist & Contrast category & 19.2 & & $.27 * * *$ \\
\hline Biblical inspired & & 32.4 & & $.08 * *$ \\
\hline Bible contains errors & & 11.8 & & $-.10 * * *$ \\
\hline Bible book of legends & & 25.1 & & $-.27 * * *$ \\
\hline Bible don't know & & 11.4 & & .02 \\
\hline Religious Practice & Standardized and summed index -3.87 & & & \\
\hline Index & $\begin{array}{l}=\text { least involved to } 4.07=\text { most } \\
\text { involved }\end{array}$ & -.26 & 2.61 & $.36^{* * *}$ \\
\hline \multicolumn{5}{|l|}{ Socio-demographics } \\
\hline Age & Age in years, 18 to 96 & 49.57 & 17.65 & $.14 * * *$ \\
\hline Female & & 52.2 & & $-.10 * * *$ \\
\hline Married & & 50.0 & & .02 \\
\hline White & & 64.8 & & $-.05^{*}$ \\
\hline South & & 37.2 & & $.14 * * *$ \\
\hline Rural & & 13.5 & & $.11 * * *$ \\
\hline Less than high school & & 8.9 & & $.16^{* * *}$ \\
\hline High school grad & & 27.1 & & $.11 * * *$ \\
\hline Some college & & 30.4 & & .03 \\
\hline College grad & Contrast category & 15.6 & & $-.14 * * *$ \\
\hline Post-graduate & & 17.7 & & $-.16 * * *$ \\
\hline$>\$ 20,000$ & & 21.1 & & $.13^{* *}$ \\
\hline$\$ 20,001-\$ 35,000$ & & 13.6 & & $.06^{*}$ \\
\hline$\$ 35,001-\$ 50,000$ & & 15.1 & & .03 \\
\hline$\$ 50,001-\$ 100,000$ & & 27.2 & & $-.06^{*}$ \\
\hline$\$ 100,000+^{\mathrm{a}}$ & Contrast category & 23.2 & & $-.14 * * *$ \\
\hline
\end{tabular}

Source: 2017 BRS (MI data)

$* \mathrm{p}<.05 ; * * \mathrm{p}<.01 ; * * * \mathrm{p}<.001$ 
Table 2: OLS Regression of Gender Traditionalism on Christian Nationalism

\begin{tabular}{|c|c|c|c|c|c|c|c|c|c|c|c|c|}
\hline \multirow[b]{2}{*}{ Variables } & \multicolumn{3}{|c|}{ Model 1} & \multicolumn{3}{|c|}{ Model 2} & \multicolumn{3}{|c|}{ Model 3} & \multicolumn{3}{|c|}{ Model 4} \\
\hline & $\beta$ & $\mathrm{b}$ & $(\mathrm{SE})$ & $\beta$ & $\mathrm{b}$ & $(\mathrm{SE})$ & $\beta$ & $\mathrm{b}$ & (SE) & $\beta$ & $\mathrm{b}$ & $(\mathrm{SE})$ \\
\hline Christian nationalism & & & & & & & & & & $.33 * * *$ & .13 & .02 \\
\hline \multicolumn{13}{|l|}{ Politics } \\
\hline Politically conservative & & & & & & & $.14 * * *$ & .75 & .17 & $.10^{* *}$ & .52 & .16 \\
\hline Politically moderate & & & & & & & --- & --- & --- & --- & --- & --- \\
\hline Politically liberal & & & & & & & $-.15 * * *$ & -.86 & .18 & $-.08 * *$ & -.45 & .17 \\
\hline \multicolumn{13}{|l|}{ Religion } \\
\hline Evangelical Protestant & & & & -- & --- & --- & --- & -- & --- & --- & --- & --- \\
\hline Mainline Protestant & & & & -.04 & -.30 & .21 & -.03 & -.25 & .20 & -.02 & -.16 & .20 \\
\hline Black Protestant & & & & -.05 & -.47 & .28 & -.03 & -.27 & .29 & -.03 & -.26 & .27 \\
\hline Catholic & & & & -.04 & -.24 & .18 & -.04 & -.22 & .17 & -.03 & -.16 & .17 \\
\hline Jewish & & & & .01 & .13 & .56 & .01 & .14 & .54 & .02 & .56 & .53 \\
\hline Other & & & & -.03 & -.25 & .27 & -.01 & -.10 & .26 & .02 & .23 & .26 \\
\hline No Religion & & & & -.05 & -.32 & .23 & -.02 & -.13 & .23 & .01 & .06 & .23 \\
\hline Biblical literalist & & & & --- & --- & --- & --- & --- & --- & --- & --- & --- \\
\hline Biblical inspired & & & & $-.09 * *$ & -.51 & .18 & $-.07 *$ & -.36 & .17 & -.04 & -.21 & .17 \\
\hline Bible contains errors & & & & $-.15 * * *$ & -1.20 & .23 & $-.11 * * *$ & -.88 & .23 & $-.07 *$ & -.51 & .23 \\
\hline Bible book of legends & & & & $-.17 * * *$ & -.99 & .25 & $-.10 *$ & -.61 & .26 & .00 & .01 & .27 \\
\hline Bible don't know & & & & -.03 & -.25 & .25 & -.01 & -.05 & .25 & .04 & .35 & .25 \\
\hline Religious Practice Index & & & & $.26 * * *$ & .25 & .03 & $.21 * * *$ & .20 & .03 & $.12 * * *$ & .12 & .03 \\
\hline \multicolumn{13}{|l|}{ Socio-demographics } \\
\hline Age & $.11 * *$ & .02 & .00 & .02 & .00 & .00 & .02 & .00 & .00 & .00 & .00 & .00 \\
\hline Female & $-.13 * * *$ & -.66 & .13 & $-.18 * * *$ & -.91 & .13 & $-.15 * * *$ & -.75 & .12 & $-.17 * * *$ & -.84 & .12 \\
\hline Married & $.07 *$ & .35 & .15 & .01 & .06 & .14 & .00 & .02 & .15 & .01 & .03 & .14 \\
\hline White & -.05 & -.24 & .14 & -.03 & -.14 & .15 & -.05 & -.28 & .15 & -.05 & -.24 & .15 \\
\hline South & $.13 * * *$ & .70 & .13 & $.06 *$ & .34 & .13 & $.06^{*}$ & .32 & .13 & $.05 *$ & .25 & .13 \\
\hline Rural & $.05^{*}$ & .41 & .19 & .03 & .21 & .18 & .02 & .15 & .17 & .02 & .12 & .17 \\
\hline Less than high school & $.19 * * *$ & 1.65 & .35 & $.16^{* * *}$ & 1.46 & .32 & $.14 * * *$ & 1.24 & .32 & $.14 * * *$ & 1.25 & .31 \\
\hline High school grad & $.16 * * *$ & .90 & .24 & $.15^{* * *}$ & .85 & .21 & $.12^{* *}$ & .67 & .21 & $.10^{* *}$ & .60 & .21 \\
\hline Some college & $.12 * *$ & .68 & .21 & $.11 * *$ & .63 & .20 & $.10 * *$ & .54 & .20 & $.09 * *$ & .49 & .19 \\
\hline College grad & --- & --- & --- & --- & --- & --- & --- & --- & --- & --- & --- & --- \\
\hline Post-graduate & -.01 & -.04 & .26 & -.01 & -.05 & .26 & .01 & .08 & .25 & .03 & .19 & .23 \\
\hline$>\$ 20,000$ & $.13^{*}$ & .79 & .31 & .08 & .48 & .28 & .09 & .58 & .28 & .08 & .47 & .28 \\
\hline$\$ 20,001-\$ 35,000$ & $.08^{*}$ & .57 & .25 & .04 & .27 & .24 & .04 & .31 & .24 & .03 & .23 & .24 \\
\hline$\$ 35,001-\$ 50,000$ & $.08^{*}$ & .54 & .26 & .03 & .23 & .26 & .05 & .34 & .26 & .04 & .30 & .24 \\
\hline$\$ 50,001-\$ 100,000$ & .03 & .15 & .21 & -.02 & -.11 & .19 & -.01 & -.08 & .19 & -.02 & -.14 & .19 \\
\hline$\$ 100,000+^{a}$ & --- & --- & --- & --- & --- & --- & --- & --- & --- & --- & --- & --- \\
\hline
\end{tabular}




\begin{tabular}{lcccc} 
Intercept & $1.71 * * *$ & $3.87 * * *$ & $3.63 * * *$ & $1.87 * * *$ \\
$\mathrm{~N}$ & 1,501 & 1,501 & 1,501 & 1,501 \\
Adj. R-square & .12 & .24 & .29 & .33 \\
\hline
\end{tabular}

Source: 2017 BRS (MI data) $* \mathrm{p}<.05 ; * * \mathrm{p}<.01 ; * * * \mathrm{p}<.001$

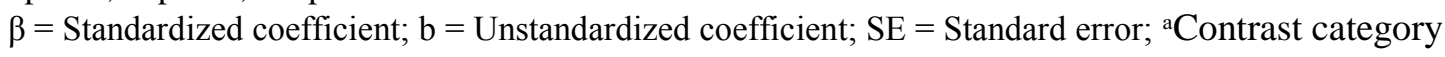


Table 3: OLS Regression of Gender Traditionalism on Christian Nationalism across Religious Traditions

\begin{tabular}{|c|c|c|c|c|c|c|c|c|c|c|c|c|}
\hline \multirow[b]{2}{*}{ Variables } & \multicolumn{3}{|c|}{ Evangelical Protestants } & \multicolumn{3}{|c|}{ Mainline Protestants } & \multicolumn{3}{|c|}{ Catholics } & \multicolumn{3}{|c|}{ Unaffiliated } \\
\hline & $\beta$ & $\mathrm{b}$ & (SE) & $\beta$ & $\mathrm{b}$ & (SE) & $\beta$ & $\mathrm{b}$ & $(\mathrm{SE})$ & $\beta$ & $\mathrm{b}$ & $(\mathrm{SE})$ \\
\hline Christian nationalism & $.24 * * *$ & .11 & .03 & $.50 * * *$ & .21 & .04 & $.20 * *$ & .09 & .03 & $.22 *$ & .10 & .04 \\
\hline \multicolumn{13}{|l|}{ Politics } \\
\hline Politically conservative & .10 & .52 & .34 & .02 & .11 & .39 & .10 & .52 & .32 & .11 & .72 & .53 \\
\hline Politically moderate & --- & --- & --- & --- & --- & --- & --- & --- & --- & --- & --- & --- \\
\hline Politically liberal & -.07 & -.57 & .47 & -.02 & -.11 & .43 & $-.14 *$ & -.82 & .35 & -.10 & -.43 & .40 \\
\hline \multicolumn{13}{|l|}{ Religion } \\
\hline Biblical literalist & --- & --- & --- & --- & --- & --- & --- & --- & --- & --- & --- & --- \\
\hline Biblical inspired & $-.11 *$ & -.62 & .28 & .08 & .41 & .51 & .06 & .27 & .44 & --- & --- & --- \\
\hline Bible contains errors & -.10 & -.88 & .50 & .00 & .02 & .57 & -.04 & -.24 & .51 & --- & --- & --- \\
\hline Bible book of legends & .03 & .29 & .54 & .10 & .58 & .60 & .02 & .13 & .58 & -.12 & -.63 & .44 \\
\hline Bible don't know & .04 & .36 & .52 & $.25 * *$ & 1.85 & .68 & -.06 & -.44 & .60 & --- & --- & --- \\
\hline Religious Practice Index & $.15^{* *}$ & .17 & .06 & .04 & .05 & .08 & .04 & .05 & .07 & -.01 & -.02 & .16 \\
\hline \multicolumn{13}{|l|}{ Socio-demographics } \\
\hline Age & -.05 & -.01 & .01 & .09 & .01 & .01 & .00 & .00 & .01 & .10 & .01 & .01 \\
\hline Female & $-.19 * * *$ & -1.00 & .23 & $-.29 * * *$ & -1.37 & .30 & -.07 & -.33 & .25 & $-.16 * *$ & -.73 & .26 \\
\hline Married & -.01 & -.04 & .28 & .10 & .49 & .41 & -.07 & -.34 & .28 & -.10 & -.45 & .32 \\
\hline White & -.04 & -.23 & .32 & -.01 & -.06 & .51 & -.05 & -.24 & .29 & -.10 & -.51 & .32 \\
\hline South & .06 & .31 & .26 & .10 & .50 & .32 & -.02 & -.13 & .28 & -.06 & -.27 & .31 \\
\hline Rural & .00 & -.01 & .33 & .05 & .35 & .46 & .08 & .58 & .49 & -.05 & -.41 & .50 \\
\hline Less than high school & $.24 * *$ & 1.98 & .61 & -.03 & -.32 & .96 & .12 & .99 & .63 & .13 & 1.27 & .99 \\
\hline High school grad & $.22 *$ & 1.19 & .46 & .11 & .58 & .50 & .04 & .23 & .42 & .08 & .41 & .42 \\
\hline Some college & $.21 *$ & 1.19 & .45 & $.19 *$ & .97 & .46 & .03 & .17 & .38 & -.04 & -.18 & .38 \\
\hline College grad & --- & --- & --- & --- & --- & --- & --- & --- & --- & --- & --- & --- \\
\hline Post-graduate & .11 & .81 & .62 & .09 & .50 & .50 & .01 & .05 & .43 & .02 & .10 & .37 \\
\hline$>\$ 20,000$ & .05 & .29 & .65 & .18 & 1.16 & .63 & .09 & .54 & .64 & .15 & .88 & .62 \\
\hline$\$ 20,001-\$ 35,000$ & .00 & .03 & .67 & .09 & .65 & .83 & .07 & .52 & .63 & -.02 & -.21 & .77 \\
\hline$\$ 35,001-\$ 50,000$ & .01 & .07 & .72 & .08 & .52 & .45 & .18 & 1.10 & .54 & -.13 & -.87 & .50 \\
\hline$\$ 50,001-\$ 100,000$ & -.04 & -.26 & .61 & .08 & .41 & .39 & .03 & .16 & .44 & -.15 & -.76 & .41 \\
\hline$\$ 100,000+^{\mathrm{a}}$ & --- & --- & --- & --- & --- & --- & --- & --- & --- & --- & --- & --- \\
\hline Intercept & $2.33^{*}$ & & & -1.07 & & & $2.03 *$ & & & $2.63 * *$ & & \\
\hline $\mathrm{N}$ & 425 & & & 202 & & & 388 & & & 243 & & \\
\hline Adj. R-square & .27 & & & .47 & & & .17 & & & .36 & & \\
\hline
\end{tabular}

Source: 2017 BRS (MI data)

$* \mathrm{p}<.05 ; * * \mathrm{p}<.01 ; * * * \mathrm{p}<.001$

$\beta=$ Standardized coefficient $; b=$ Unstandardized coefficient; SE = Standard error; ${ }^{a}$ Contrast category 
Figure 1: Mean Scores and Predicted Values on Gender Traditionalism Scale by Christian Nationalism

12

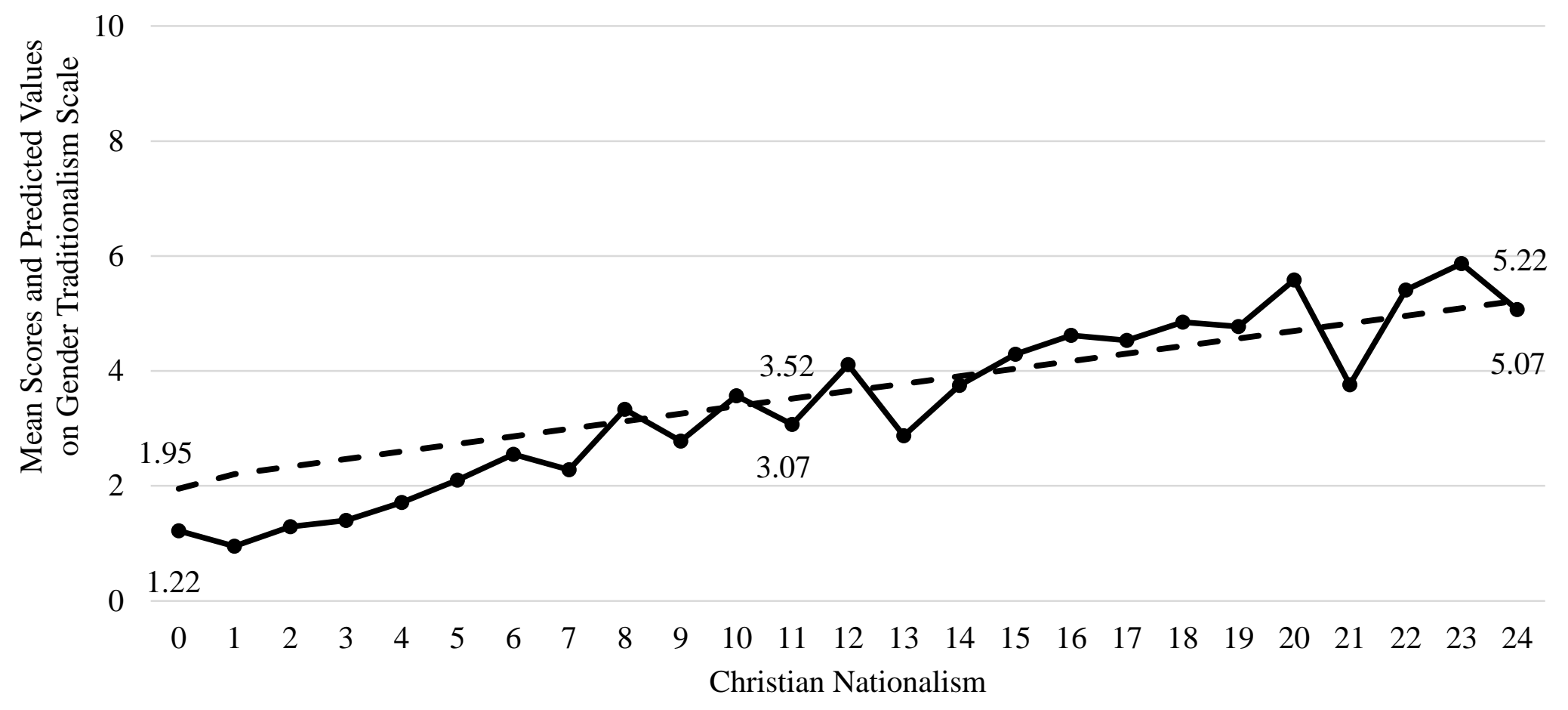

$\longrightarrow$ Mean Scores $\quad$ - - Predicted Values 
Figure 2: Predicted Scores on Gender Traditionalism Scale by Christian Nationalism across Religious Traditions

12

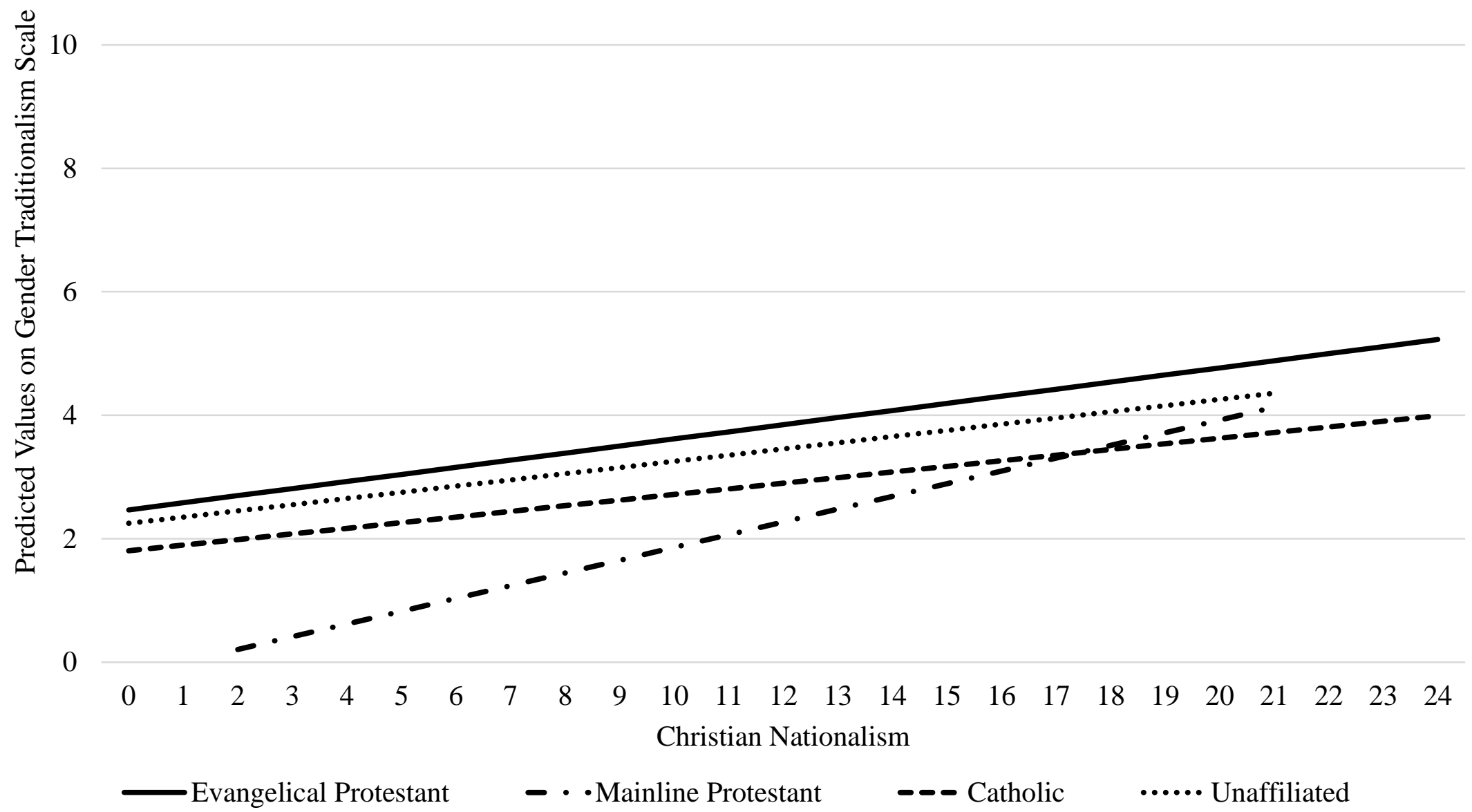

Note: All significant correlates in full model held at means or measures of central tendency. Unaffiliated prediction line ends at 23 because no unaffiliated respondents scored higher than this on the Christian nationalism scale. 